\title{
Hubungan Sikap Asertif Dan Rasa Malu Terhadap Perilaku Anti Korupsi Pada Remaja
}

\author{
Hesty Yuliasar dan Putri Pusvitasari \\ Program Studi Psikologi, Universitas Jenderal Achmad Yani Yogyakarta \\ Penulis Korespondensi: hestyyuliasari.psi@yahoo.com
}

\begin{abstract}
ABSTRAK
Penelitian ini bertujuan untuk mengetahui dan menguji secara empiris hubungan antara sikap asertiif dan rasa malu terhadap perilaku anti korupsi pada remaja. Subjek yang terlibat dalam penelitian ini adalah remaja berjenis kelamin laki-laki dan perempuan dengan rentang usia 13 hingga 18 tahun. Penelitian ini menggunakan tiga skala yaitu skala sikap asertif (35 aitem, $\alpha=$ 0.793 ), skala kedua adalah skala rasa malu (16 aitem, $\alpha=0.794)$. Alat ukur yang ketiga adalah kuesioner yang digunakan oleh Badan Pusat Statistik saat survey pengukuran indeks perilaku anti korupsi (IPAK) tahun 2012 (20 aitem, $\alpha=0.771$ ). Skala dan kuesioner dimodifikasi oleh peneliti menyesuaikan karakteristik subjek. Pemilihan subjek dilakukan dengan cara purposive sampling. Analisis data dilakukan dengan uji regresi linier berganda dan uji tambahan menggunakan independent sample t-test program IBM SPSS 20.0 realease for Windows. Hasil analisis regresi berganda dilakukan untuk menguji hubungan antara tiga variabel penelitian, yaitu sikap asertif dan rasa malu terhadap perilaku anti korupsi memiliki hubungan yang positif terhadap perilaku anti korupsi pada remaja $(B=2.618, p=0.008)$. Hasil analisis regresi sederhana menunjukkan hubungan sikap asertif dan perilaku anti korupsi memiliki hubungan positif $(\mathrm{B}=2.223, \mathrm{p}=0.03)$ dan hasil analisis regresi menunjukkan hubungan rasa malu dan perilaku anti korupsi memiliki hubungan positif $(B=0.99, p=0.04)$. Analisis tambahan untuk melihat pengaruuh jenis kelamin terhadap masing-masing variabel menunjukkan bahwa ada perbedaan sikap asertif, rasa malu dan perilaku anti korupsi berdasarkan jenis kelamin, sedangkan berdasarkan tingkat pendidikan tidak memiliki perbedaan. Hasil penelitian ini menunjukkan bahwa untuk meningkatkan perilaku anti korupsi tidak hanya dibutuhkan sikap asertif saja namun juga rasa malu terhadap perilaku tidak bermoral juga sangat dibutuhkan.
\end{abstract}

Kata Kunci: Sikap Asertif, Rasa Malu, Perilaku Anti Korupsi, Remaja

\section{PENDAHULUAN}

Masa remaja merupakan masa peralihan dari masa kanak-kanak yang mengalami perkembangan pada semua aspek atau fungsi untuk memasuki masa dewasa. Mappiare menjabarkan masa remaja sebagai sebuah masa yang berlangsung antara usia 12 tahun sampai dengan 21 tahun bagi wanita. Sedangkan pria berlangsung dari usia 13 tahun sampai dengan 22 tahun (Ali \& Asrori, 2016). Desmita menyatakan bahwa masa remaja ditandai dengan sejumlah karakteristik penting yang meliputi pencapaian hubungan yang matang dengan teman sebaya, dapat menerima dan belajar mengenai peran sosial sebagai pria atau wanita yang dijunjung tinggi oleh masyarakat, menerima keadaan fisik dan mampu menggunakannya secara efektif sehingga mengembangkan keterampilan intelektual dan konsep-konsep yang dibutuhkan sebagai warga negara, mencapai tingkah laku yang bertanggungjawab secara sosial dan memperoleh seperangkat nilai dan sistem etika sebagai pedoman dalam bertingkah laku (Desmita, 2011).

Dengan menyadari perannya tersebut, para remaja sebagai generasi muda ini diharapkan memiliki keinginan untuk mencegah korupsi agar tidak terjadi di masa yang akan datang. 
Berdasarkan Laporan Tahun Indoesian Corruption Watch 2019 menunjukkan bahwa 271 kasus korupsi yang ditangani oleh Kejaksaan Agung, Kepolisian dan Komisi Pemberantasan Korupsi (KPK) dengan jumlah tersangka 580 orang, kerugian negara Rp8,4 triliun, jumlah suap Rp200 miliar, pungutan liar Rp3,7 miliar dan jumlah pencucian uang Rp108 miliar (antikorupsi.org, diakses 18 April 2021). Pada 2017 ada 576 perkara yang disidik, kemudian pada 2018 menjadi 454 kasus, pada 2019 menurun jadi 271. Adanya penurunan kasus sangat signifikan pada tiga Lembaga tersebut yang artinya perkara kasus berkaitan dengan penetapan tersangka hingga ke meja hijau. Hal ini menunjukkan bahwa angka korupsi di Indonesia cukup tinggi.

Pencegahan kasus korupsi di Indonesia dapat dimulai dari tatanan sosial yang terendah yaitu pada penanaman nilai dan sikap anti korupsi pada Remaja. Studi pendahuluan yang dilakukan pada mahasiswa di Fakultas Ekonomi dan Sosial, Universitas Jenderal Achmad Yani Yogyakarta pada mahasiswa dengan rentang usia remaja akhir menunjukkan bahwa $47 \%$ Responden sudah memiliki pengetahuan tentang perilaku korupsi, namun masih terdapat 53\% responden yang perlu di tingkatkan pengetahuan dan pemahamannya akan perilaku korupsi (Heryadi \& Yuliasari, 2019). Hasil penelitian ini dapat menegaskan bahwa remaja membutuhkan pemahaman dan penanaman nilai anti korupsi. Pemahaman dan penanaman nilai dapat diberikan dengan pendidikan anti korupsi. Pendidikan anti korupsi yang berbentuk pelatihan anti korupsi pada mahasiswa efektif untuk meningkatkan perilaku anti korupsi. Penelitian Yuliasari dan Heryadi (2020) ketika sebelum diberikan pelatihan anti korupsi IPAK mahasiswa adalah 2,45 dan setelah diberikan pelatihan IPAK sebesar 2,79. Hal ini menunjukkan adanya peningkatan IPAK mahasiswa meskipun tidak sangat signifikan. Penanaman nilai-nilai anti korupsi harus juga diikuti dengan pemahaman terhadap fenomena sosial masyakarat sehingga remaja mampu memiliki sikap enggan untuk terlibat dalam aktivitas korupsi.

Pandangan remaja mengenai korupsi berkaitan dengan integritas seseorang karena masa remaja adalah waktu yang tepat untuk membangun posisi yang tepat dalam ruang lingkup sosial. Survei yang dilakukan pada remaja Indonesia mengenai korupsi merujuk pada perilaku mengambil uang dan mendapatkan keuntungan pribadi untuk dirinya sendiri, sehingga tergolong tidak memiliki integritas diri. Survei ini menunjukkan bahwa asertif, konsisten, jujur dan bertanggung jawab menunjukkan individu yang memiliki integritas sehingga mampu menolak untuk melakukan korupsi (Sihombing, 2018). Remaja yang mampu menyadari perannya akan dapat mengemukakan pendapat dan berani untuk berkata tidak pada korupsi. Remaja yang mampu menyuarakan pendapatnya tanpa menyakiti orang lain dapat dikatakan sebagai remaja yang asertif.

Sikap asertif adalah sikap mengekspresikan diri secara langsung dan jujur dalam situasi interpersonal dengan menghormati hak dan martabat orang lain (Dagnew \& Astrat, 2017). Hal ini mengindikasikan bahwa asertif melibatkan kognitif dan afektif pada remaja. Remaja yang asertif mampu mengekspresikan dan bereaksi terhadap emosi positif dan negatif tanpa kecemasan yang tidak semestinya ataupun agresi (Uzaina \& Parven, 2015). Sikap asertif penting dimiliki oleh remaja karena akan memudahkan remaja dalam bersosialisasi dan menjalin interaksi dengan lingkungan, membantu remaja mengekspresiakan diri dan keinginan secara langsung dan jujur, mencari solusi dan penyelesaian dari masalah yang dihadapi dan meningkatkan kemampuan berfikir, memperluas wawasan dan tidak mudah putus asa serta meningkatkan rasa ingin tahu dalam diri (Bhardwaj \& Vishwas, 2019).

Alberti dan Emmons menyebutkan faktor-faktor yang mempengaruhi sikap asertif yaitu jenis kelamin, harga diri, kebudayaan, tingkat Pendidikan, tipe kepribadian dan situasi tertentu di lingkungan sekitarnya (Afnanjaya \& Indrawati, 2016). Jenis kelamin berkontribusi terhadap tinggi rendahnya sikap asertif individu. Laki-laki cenderung memiliki asertivitas yang lebih tinggi dibandingkan perempuan karena adanya tuntutan masyarakat bahwa laki-laki diharapkan lebih aktif dan kompetitif. Sedangkan perempuan lebih cenderung berbelas kasih 
dan berfokus pada rasa empati yang besar sehingga cenderung lebih rentan terhadap perasaan berkecil hati yang membuat perempuan menjadi sulit dalam mengambil keputusan secara logis (Dagnew \& Astrat, 2017).

Dalam mempertahankan hak-hak pribadinya, remaja harus terlebih dahulu mengetahui hak-haknya. Selain itu, dalam berperilaku asertif remaja akan menyatakannya dengan sopan, tenang, sesuai dengan adat dan rendah hati untuk meminta orang lain melakukan apa yang dikehendaki. Perilaku asertif terbentuk dari hubungan timbal balik antar remaja dengan masyarakat, komunitas ataupun antar individu yang baik. Namun, ketika hubungan tersebut tidak seimbang, perilaku asertif cenderung mengarah pada perilaku agresif sehingga mengesampingkan rasa malu dalam mengekspresikan emosi diri.

Berdasarkan wawancara pendahuluan pada beberapa remaja SMA yang peneliti temui, diketahui bahwa beberapa hal yang dapat membuat seseorang menahan diri untuk tidak melakukan perbuatan yang negatif dan melanggar norma di masyarakat, adalah adanya rasa malu dalam diri. Perilaku melanggar norma ini seperti perilaku menyontek, berbohong dalam hal apapun, terlambat atau korupsi waktu, serta hal-hal yang bertujuan untuk menguntungkan diri sendiri. Ada perasaan cemas yang muncul apabila melakukan tindakan melanggar norma tersebut. Perasaan cemas ini muncul karena takut jika perbuatannya diketahui oleh orang lain sehingga menyebabkan rasa malu, yang pastinya tidak hanya dirinya saja yang akan menanggung malu, tetapi juga keluarganya.

Kondisi ini sejalan pula dengan penelitian Anggarasari dan Kumolohadi (2012) bahwa dalam beberapa budaya di Indonesia, seseorang yang menanggung rasa malu akibat perbuatannya, tidak hanya ditanggung oleh dirinya sendiri, melainkan juga oleh keluarganya. Sifat laki-laki dan perempuan terbentuk dari lingkungan sosial, maka masing-masing identitas gender diajarkan tindakan berbeda dalam mengekspresikan rasa malu, sementara perempuan cenderung untuk menarik diri dan menghindar ketika merasa malu, sedangkan laki-laki akan cenderung menyerang apabila dia merasa dipermalukan (Dagnew \& Astrat, 2017).

Menurut studi Cunha, Matos, Faria, dan Zagalo, (2012) masa remaja merupakan masa dimana individu lebih tinggi merasa malu dibandingkan pada masa dewasa. Berdasarkan penelitian-penelitian sebelumnya terkait rasa malu, rendah diri, kecemasan, dan rasa rendah pada remaja, dapat diketahui bahwa rasa malu memiliki peran penting dalam kesehatan dan kesejahteraan remaja. Individu dengan rasa malu akan cenderung menjaga sikapnya untuk tidak melakukan hal-hal yang negatif dan melanggar norma, dalam hal ini misalnya saja seperti melakukan tindak korupsi. Hal ini sejalan dengan penelitian Anggarasari dan Kumolohadi (2012) dimana rasa malu sesungguhnya merupakan sesuatu yang sehat karena dapat mendorong seseorang untuk menjaga sikap dan harga dirinya.

Rasa malu juga dapat dilihat sebagai sesuatu hal yang positif karena rasa malu ini dapat membantu individu yang pemalu untuk dapat menghindari konflik atau mengintimidasi orang lain serta memberikan perubahan untuk bertahan, menggambarkan tentang situasi dan mengobservasi orang lain dalam lingkungan, dan dapat memberikan kesan sebagai orang yang pandai, rendah hati, atau sederhana dan bijaksana (Cunha dkk, 2012). Sebagaimana pula yang diungkapkan oleh Tangney, Stueig, dan Martinez dalam studinya, bahwa rasa malu dapat menghambat munculnya perilaku tidak bermoral atau kriminal orang dewasa (Tangney, Stuewig, \& Martinez, 2014).

Perilaku anti korupsi sangat erat kaitannya dengan dua faktor, yaitu faktor internal dan faktor eksternal. Kemendikbud, (2011) menjelaskan Faktor internal merupakan penyebab korupsi yang datang dari diri pribadi sedang faktor eksternal adalah faktor penyebab terjadinya korupsi karena sebab-sebab dari luar. Faktor internal terdiri dari; (1) aspek moral, misalnya lemahnya keimanan, kejujuran, rasa malu, (2) aspek sikap atau perilaku misalnya pola hidup konsumtif dan (3) aspek sosial seperti keluarga yang dapat mendorong seseorang untuk berperilaku korup. Sedangkan faktor eksternal bisa dilacak dari; (1) aspek ekonomi misalnya 
pendapatan atau gaji tidak mencukupi kebutuhan, (2) aspek politis misalnya instabilitas politik, kepentingan politis, meraih dan mempertahankan kekuasaan, (3) aspek managemen \& organisasi yaitu ketiadaan akuntabilitas dan transparansi, (4) aspek hukum, terlihat dalam buruknya wujud perundangundangan dan lemahnya penegakkan hukum serta (5) aspek sosial yaitu lingkungan atau masyarakat yang kurang mendukung perilaku anti korupsi.

Remaja yang asertif mampu mengembangkan diri dan memiliki pencapaian pribadinya secara penuh. Kemampuan asertif pada bidang komunikasi akan meningkatkan kompetensi sosialnya. Dengan adanya kemampuan sosial dalam berkomunikasi akan membuat remaja mampu untuk mengekpresikan diri terhadap ketidaksukaannya pada perilaku korupsi. Korupsi tidak hanya mengimplikasi standar etik untuk diri remaja itu, sendiri namun juga bertentangan dengan hokum (Cohen dkk, 2017). Penelitian Li dan Wu menjelaskan bahwa negara yang memiliki level of justice yang rendah antar warga negaranya akan menjadi sasaran korupsi yang cukup tinggi. Remaja cenderung mengikuti persepsi dalam grup sebayanya untuk dapat mengambil keputusan dan mengekpresikan diri. Hubungan dengan teman sebaya yang saling mendukung dalam hal kebaikan akan berdampak positif. Tetapi apabila teman sebaya cenderung mengajak pada hal-hal yang maladaptif, maka akan berdampak negatif kecuali remaja tersebut memiliki sikap asertif yang tinggi. Sikap asertif dapat mencegah remaja ikut serta dalam konformitas negatif karena remaja mampu menolak dengan tegas (Aryani, 2019).

Remaja yang asertif akan mampu untuk bertindak sesuai dengan kepentingan dan minatnya. Remaja yang memiliki fokus pada isi dari tujuan dan sesuai dengan yang benarbenar ingin dilakukannya merupakan tujuan realistic yang bisa dilakukan oleh remaja tersebut (Beal \& Crockett, 2013). Remaja yang realistis dan memiliki tujuan akan membentengi dirinya dari intensi terhadap perilaku korupsi sehingga memilah hak yang pantas untuknya dan kewajiban yang harus dilakukannya sehingga menjadikan dirinya pribadi yang bertanggung jawab sebagai bentuk asertif diri. Hal ini berlaku pada sikap anti korupsi pada remaja dimana remaja menjadi disiplin melakukan sesuatu sesuai dengan porsinya secara terbuka dan nyaman. Pada perilaku anti korupsi sikap terbuka diasosiasikan dengan kejujuran. Sikap asertif dan kejujuran saling berkorelasi dimana integritas dalam perilaku anti korupsi erat kaitannya dengan kejujuran dan ketegasan (Sihombing, 2018).

Rasa malu merupakan bentuk sikap yang sangat dirasakan oleh individu saat tidak dapat mentaati peraturan yang ada di masyarakat. Dalam kebudayaan masyarakat, individu bekerja untuk mengembangkan potensinya, mentaati peraturan yang ada di masyarakat, dapat menjalankan amanah, dan melakukan sesuatu sesuai dengan hati nuraninya. Dengan begitu, individu diharapkan tidak akan melakukan perilaku korupsi (Rusdi \& Prasetyaningrum, 2015). Fokus dari rasa malu ada pada penilaian negatif terhadap keseluruhan diri individu. Ada dua dimensi rasa malu menurut Cohen, dkk, yaitu Negative Self Evaluation dan Withdraw. NSE ini mengacu pada konsep malu yang dikaitkan dengan pengakuan telah melakukan kesalahan yang mengakibatkan individu memiliki kepercayaan bahwa komponen kepribadian atau diri mereka cacat, atau sudah merugikan diri sendiri atau orang lain, (2) Withdraw, dimensi ini mengacu pada penarikan individu dari masyarakat, dan sering bersembunyi atau melarikan diri dari situasi (Cohen dkk, 2011).

Seperti yang diungkapkan oleh Hasanah, dimana perilaku korupsi secara umum memiliki dampak psikologis yang besar dalam masyarakat berupa dampak psikososial, dimana munculnya perasaan malu disertai dengan tekanan mental akibat proses isolasi dari masyarakat, khususnya pada perkembangan anak-anaknya (Khodijah, 2018). Masyarakat dalam lingkup sosial biasanya memiliki stigma negatif untuk para pelaku korupsi, dimana mereka menganggap bahwa pelaku korupsi sangat tidak layak hidup berdampingan dengan masyarakat. Hal ini karena stereotip sosial di masyarakat yang berpikir bahwa dimana pelaku korupsi ada, maka pelaku akan selalu melakukan korupsi. Pandangan seperti ini tentu saja memunculkan tekanan psikologis tersendiri bagi para pelaku korupsi. 
Perasaan malu tersebut akan membuat orang yang bersangkutan merasa tidak nyaman dan merasa diasingkan. Hal ini sejalan pula dengan studi Hasanah (2011) dimana masyarakat akan berupaya melakukan isolasi sosial terhadap seluruh aspek kehidupan. Kondisi ini akan semakin mempersulit ruang gerak para pelaku korupsi. Apabila perasaan malu ini dijadikan sebagai sebuah budaya, maka hal tersebut akan membatasi seseorang agar tidak melakukan sesuatu hal yang membuat dirinya sendiri menanggung rasa malu dan justru akan semakin meningkatkan perilaku anti korupsi dalam diri individu. Individu yang melakukan tindak korupsi akan memanfaatkan potensi-potensi yang ada pada dirinya hanya pada saat mendapatkan imbalan atau hadiah dari individu lain untuk melakukan tugasnya. Individu tersebut juga tidak memiliki rasa malu dan rasa bersalah karena tidak mentaati peraturan yang ada di dalam masyarakat.

\section{METODE PENELITIAN}

Penelitian ini melibatkan 60 remaja SMP dan SMA, pria dan wanita dengan rentang usia 13 18 tahun menggunakan teknik purposive sampling dengan mengambil sampel orang-orang yang dipilih oleh penulis menurut ciri-ciri spesifik dan karakteristik tertentu. Instrumen penelitian yang digunakan untuk mengukur sikap asertif mengacu pada teori Alberti dan Emmons (Anfanjaya \& Indrawati, 2016), instrumen ini terdiri dari 35 aitem dengan koefisien reliabilitas bergerak dari $0.301-0.659$, dengan nilai alpha Cronbach 0.793. Rasa malu berdasarkan teori Cohen dkk (2017) dengan koefisien reliabilitas bergerak dari $0.311-0.724$, dengan nilai alpha Cronbach 0.794. Instrumen penelitian yang digunakan untuk mengukur perilaku anti korupsi dalam penelitian ini adalah berupa kuesioner yang digunakan oleh Badan Pusat Statistik saat survey pengukuran indeks perilaku anti korupsi (IPAK) tahun 2012 yang dimodifikasi kuesioner sebanyak 20 aitem agar sesuai dengan karakteristik responden yaitu remaja SMP dan SMA dengan koefisien reliabilitas bergerak dari $0.304-0.696$, dengan nilai alpha Cronbach 0.771. Analisis data dilakukan dengan uji regresi linier berganda dibantu dengan program IBM SPSS 20.0 realease for Windows. Analisis regresi linier berganda dilakukan untuk menguji hubungan antara tiga variabel penelitian, yaitu sikap asertif dan rasa malu terhadap perilaku anti korupsi.

\section{HASIL DAN PEMBAHASAN}

Data sebaran skor sikap asertif, rasa malu dan perilaku anti korupsi pada remaja dapat dilihat pada gambar berikut ini.

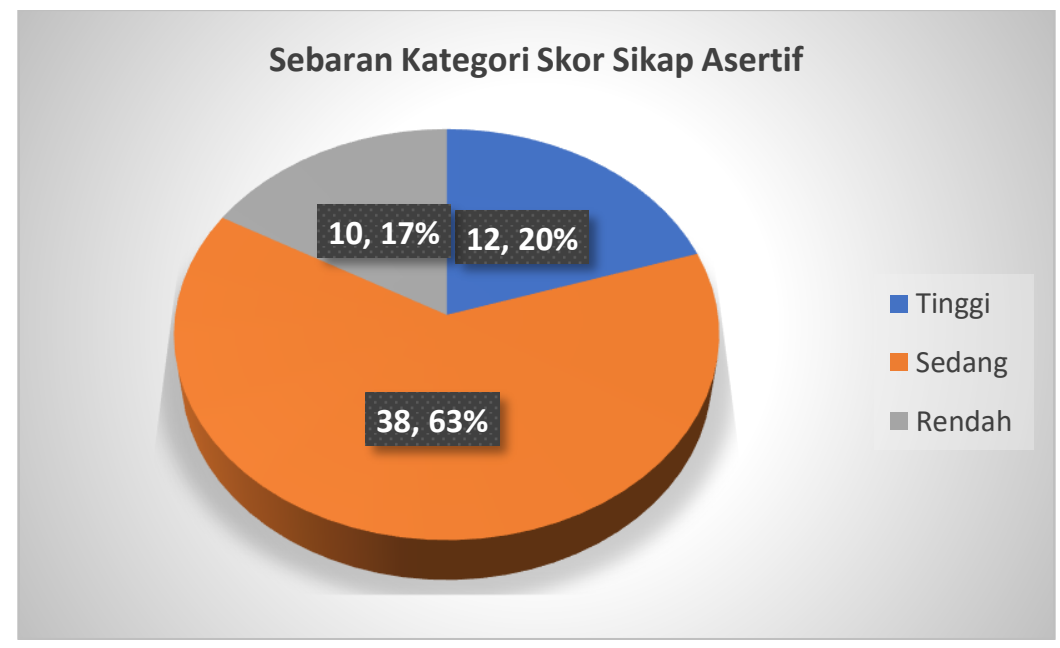

Gambar 1. Sebaran kategori sikap asertif responden 


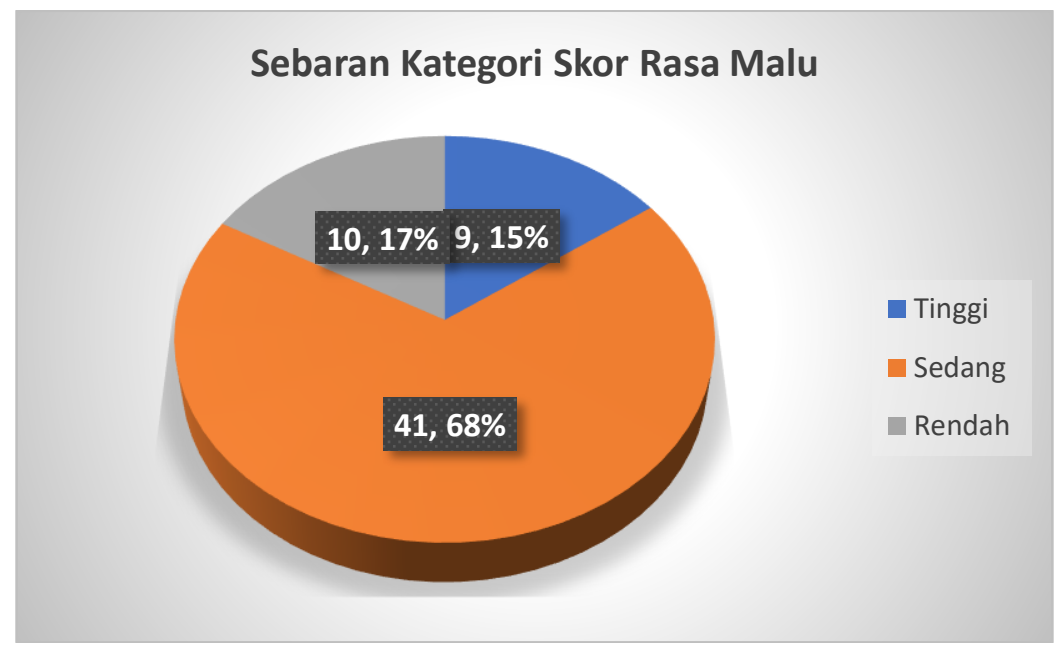

Gambar 2. Sebaran Kategori Rasa malu

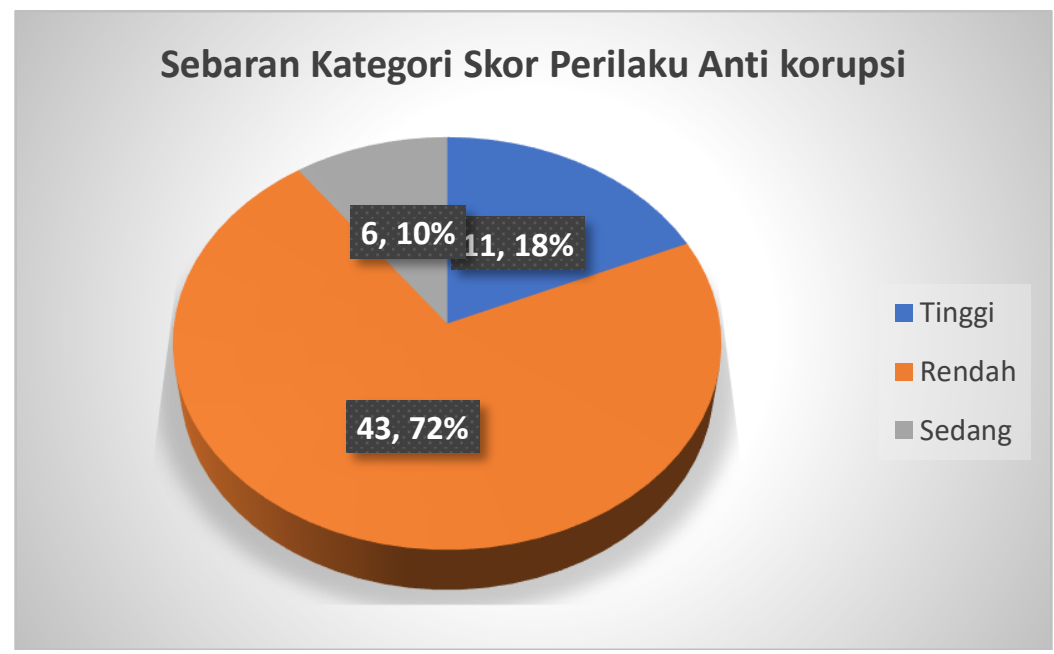

Gambar 3. Sebaran Kategori Perilaku Anti korupsi

Sebaran kategori skor responden penelitian sebagian besar berada pada kategori sedang. Hal ini menunjukkan bahwa sikap asertif, rasa malu dan perilaku anti korupsi masih menjadi membutuhkan pendalaman pemahaman bagi setiap remaja. Hal ini akan membuat remaja mengembangkan perilaku yang bertentangan dengan norma sosial kedepannya sehingga bisa terjerumus perilaku korupsi (Mukodi, 2018). Masih banyak remaja yang menganggap korupsi bukanlah bagian dari ruanglingkup usianya sehingga mempengaruhi remaja dalam mengemukakan pendapat, mengungkapkan ketidak sukaan dan ketidak setujuan dalam aturan yang tidak jelas dan berkembang menjadi rasa tidak peduli dan acuh sehingga memunculkan perilaku tidak sopan dan tanpa rasa malu.

Melalui hasil uji regresi dapat disimpulkan sikap asertif dan rasa malu memiliki hubungan yang positif terhadap perilaku anti korupsi pada remaja. Selain itu untuk melihat hubungan sikap asertif terhadap perilaku anti korupsi dan hubungan rasa malu terhadap perilaku anti korupsi maka dilakukan uji analisis regresi untuk masing-masing variabel bebas.

Tabel 1. Hasil analisis regresi berganda

\begin{tabular}{|l|cc|}
\hline \multicolumn{1}{|c|}{ Variabel } & B & Sig. \\
\hline $\begin{array}{l}\text { Sikap asertif dan rasa malu * } \\
\text { perilaku anti korupsi }\end{array}$ & 2.618 & 0.008 \\
\hline
\end{tabular}


Analisis data yang dilakukan dalam penelitian ini menunjukkan bahwa sikap asertif dan rasa malu memiliki hubungan yang positif terhadap perilaku anti korupsi, yang artinya semakin tinggi sikap asertif dan rasa malu pada remaja maka akan semakin tinggi pula perilaku anti korupsinya. Hal ini sejalan dengan penelitian Widyastuti (2017) bahawa orang asertif akan cenderung jujur dan memiliki pemikiran positif tentang dirinya dan orang lain tanpa memandang rendah orang lain. Jujur dalam bertindak sesuai dengan nilai-nilai anti korupsi yang diterapkan dapat ditunjukkan dengan mengatakan sesuatu sesuai dengan yang benarbenar dirasakan dan dialami (Heryadi, Yuliasari, Ambarwati \& Fathurosyiddin, 2021). Remaja yang asertif akan jujur dalam mengekspresikan perasaan, pendapat dan kebutuhan yang sesuai tanpa memanipulasi dan memanfaatkan orang lain ataupun merugikan pihak lain merupakan implementasikan perilaku anti korupsi. Perilaku anti korupsi harus dibentuk sejak dini sehingga menjadikan individu sebagai pribadi yang anti korupsi yang memunculkan sikap menjaga diri, memiliki rasa malu, dan selalu merasa cukup (Khosiin, 2020).

Tabel 2. Hasil Uji regresi sederhana

\begin{tabular}{|c|c|c|}
\hline Variabel & Sig & Keterangan \\
\hline Sikap asertif * perilaku anti korupsi & $0.03(\mathrm{p}<0.05)$ & signifikan \\
\hline Rasa Malu * Perilaku anti korupsi & $0.04(\mathrm{p}<0.05)$ & signifikan \\
\hline
\end{tabular}

Berdasarkan table diatas menunjukkan bahwa hubungan masing-masing variabel bebas terhadap variabel tergantung memiliki korelasi yang signifikan. Nilai koefisien regresi variabel sikap asertif sebesar 2.223 memiliki arti bahwa setiap adanya peningkatan skor pada sikap asertif maka tingkat perilaku anti korupsi akan meningkat sebesar 2.223. Selain itu, nilai koefisien regresi variabel rasa malu sebesar 0.991 memiliki arti bahwa setiap adanya peningkatan skor pada rasa malu maka tingkat perilaku anti korupsi akan meningkat sebesar 0,991. Besarnya sumbangan sikap asertif dan rasa malu dapat dilihat pada table berikut:

\section{Tabel 3. Sumbangan sikap asertif dan rasa malu terhadap perilaku anti korupsi}

\begin{tabular}{|c|cc|}
\hline Variabel & $\mathbf{R}$ & $\mathbf{R}^{2}$ \\
\hline ap asertif *rasa malu * perilaku anti korupsi & 0.890 & 0.520 \\
\hline
\end{tabular}

Berdasarkan output dari hasil analisis regresi berganda yang telah dilakukan pada hubungan antara sikap asertif, rasa malu dan perilaku anti korupsi ddiperoleh nilai koefisien korelasi (R) $=0.890$ dengan nilai koefisien determinasi $\left(\mathrm{R}^{2}\right)=0.520$ yang memiliki arti bahwa secara bersama-sama Sikap asertif dan rasa malu memberikan sumbangan efektif sebesar $52.0 \%$ terhadap perilaku anti korupsi, sedangkan sisanya sebesar $48.0 \%$ ditentukan karena adanya faktor lain yang tidak disebutkan dalam penelitian ini. Dalam sikap asertif, tercermin perilaku yang memiliki nilai integritas yang juga akan mempengaruhi sikap individu dalam menolak sesuatu yang tidak sesuai dengan dirinya, hal ini juga tercermin dari perilaku anti korupsi di lingkungannya. Studi survei yang dilakukan untuk melihat persepsi anak muda terhadap integritas menunjukkan bahwa integritas dianggap sebagai karakter individu konsistensi, kejujuran, koherensi antara prinsip dan tindakan, tanggung jawab, keadilan, kepercayaan, komitmen, rasa hormat, tanggung jawab, dan asertif (Sihombing, 2018). Hal ini sejalan pula dengan hasil penelitian bahwa perilaku rasa malu tercermin sikap moral dan sikap etis terhadap perilaku anti korupsi. Persepsi etis siswa adalah bagaimana siswa bersikap menilai satu keadaan atau perilaku pelanggaran sehingga tidak melakukan penyalahgunaan sumber daya, pencurian, penipuan dan korupsi yang merupakan tindakan atau perilaku yang bertentangan dengan nilai-nilai anti korupsi (Triyana \& Heryadi, 2020).

Hasil penelitian ini sejalan dengan penelitian yang dilakukan oleh Abraham, Kurniadi, Andangsari, Ali, Manurung, \& Warnars (2020) bahwa perilaku korupsi yang lebih intensif 
dan berulang, dan lebih besar toleransi terhadap perilaku koruptif terdapat pada masyarakat dengan tingkat rasa bersalah dan malu. Anak-anak yang mendekati usia remaja lebih menyukai aspirasi dan mengharapkan persetujuan daripada orang lain atau referensi kelompoknya untuk membangun identitas diri yang positif. Hal ini mempengaruhi bagaimana perkembangan moral berupa rasa malu dan rasa bersalah yang berkontribusi terhadap pelepasan moral melalui interaksi dengan teman sebaya terkait dengan persepsi perilaku yang mengarah pada korupsi (Abraham, dkk 2020).

Analisis tambahan yang dilakukan bertujuan untuk menguji sikap asertif, rasa malu dan perilaku anti korupsi berdasarkan jenis kelamin dan tingkat pendidikan pada remaja. Perbedaan sikap asertif pada remaja laki-laki dan perempuan didasari dari Independent Sample T-Test memperoleh hasil signifikansi $\mathrm{p}=0.08(\mathrm{p}<0.05)$ sehingga dapat dikatakan ada perbedaan antara sikap asertif pada remaja laki-laki maupun perempuan. Selanjutnya perbedaan rasa malu pada remaja laki-laki dan perempuan dalam penelitian ini memiliki hasil signifikansi sebesar $\mathrm{p}=0.031(\mathrm{p}<0.05)$ yang berarti bahwa terdapat juga perbedaan rasa malu antara laki-laki dan perempuan. Kemudian, perbedaan perilaku anti korupsi pada remaja lakilaki dan perempuan didasari dari Independent Sample T-Test memperoleh hasil signifikansi p $=0.045(\mathrm{p}<0.05)$ sehingga dapat dikatakan terdapat perbedaan perilaku anti korupsi pada remaja laki-laki maupun perempuan.

Dalam peneltiian ini menunjukkan bahwa jenis kelamin mempengaruhi sikap asertif, rasa malu dan perilaku anti korupsi pada remaja, dimana ada perbedaan pada laki-laki dan perempuan. Isu gender menjadi bahasan yang menarik terkait variabel penelitian ini. Beberapa penelitian terdahulu menjelaskan bahwa hasil survei menunjukkan bahwa perempuan cenderung kurang egois dan memiliki standar moral dan etika yang lebih tinggi daripada pria (Branisa \& Ziegler, 2011). Menempatkan perempuan ke dalam institusi publik akan mengurangi korupsi karena standar etika dan moral perempuan yang tinggi. Sebaliknya laki-laki adalah dianggap memiliki sifat untuk mengontrol, mendominasi dan agresif, dan sifat-sifat ini cenderung cocok dengan korupsi (Widoyoko, 2013).

Perempuan cenderung lebih asertif dalam bersikap. Penelitian Parham, Lewis, Fretwell, Irwin, \& Schrimsher (2015) menyebutkan perempuan yang tegas akan menjadi pemimpin dalam kelompok karena kecenderungannya untuk berbicara dan bertindak demi kepentingan terbaik kelompok tanpa kecemasan daripada laki-laki. Selain itu, penelitian mengenai rasa malu berkaitan dengan atribusi internal terhadap pelanggaran etika, dimana pelanggaran etika ini bisa berkaitan dengan perilaku korupsi. Menurut Brophy dan Kuger (dalam Budiarto, 2019) rasa bersalah terhadap peristiwa yang melanggar etika lebih muncul pada perempuan karena berkaitan dengan rasa bersalah terhadap lingkungan, sedangkan pada laki-laki lebih mengarah pada rasa bersalah terhadap diri sendiri.

\section{KESIMPULAN}

Berdasarkan pembahasan yang telah diuraikan mengenai hubungan sikap asertif dan rasa malu terahdap perilaku anti korupsi pada remaja maka dapat ditarik kesimpulan dan saran sebagai berikut:

1. Terdapat hubungan sikap asertif dan rasa malu terhadap perilaku anti korupsi pada remaja yang membuat remaja memiliki persepsi negatif terhadap perilaku yang tidak bermoral dan mengembangkan budaya rasa malu.

2. Ada hubungan sikap asertif terhadap perilaku anti korupsi yang tercermin dalam integritas dan nilai-nilai anti korupsi salah satunya kejujuran dalam situasi apapun.

3. Ada hubungan rasa malu terhadap perilaku anti korupsi yang tercermin sikap moral dan sikap etis terhadap perilaku anti korupsi sehingga tidak melakukan penyalahgunaan perilaku yang bertentangan dengan nilai-nilai anti korupsi 
4. Selain faktor sikap asertif dan rasa malu, perilaku anti korupsi dapat dipengaruhi oleh faktor-faktor lainnya berupa jenis kelamin, dan pemahaman terhadap emosi seperti perasaan bersalah.

Saran untuk pengembangan lebih lanjut terhadap penelitian ini, ada beberapa saran yang dapat diambil:

1. Peneliti selanjutnya dapat memperluas variabel pada peran lingkungan eksternal terhadap perilaku anti korupsi sehingga dapat meneliti berbagai faktor lainnya

2. Bagi pihak sekolah dan tenaga pendidik dapat mengintegrasikan nilai-nilai anti korupsi agar dapat diimplementasikan di usia remaja melalui lingkungan terdekat.

3. Bagi keluarga dapat menerapkan perilaku anti korupsi yang tercermin sehari-hari agar perilaku siswa menjadi lebih asertif dan mengenal rasa malu.

\section{DAFTAR PUSTAKA}

Abidin, Z., \& Siswadi, A. G. P. (2015). Psikologi Korupsi. Bandung: Remaja Rosdakarya Abraham,J, Kurniadi, M. A, Andangsari, E. W., Ali, M.M., Manurung, R. H., \& Warnars, H. L. H. S. (2020). Prediction of guilt and shame proneness based on disruption to psychological contract: A new light for corruption prevention. Heliyon, 6(6), e04275. doi:10.1016/j.heliyon.2020.e04275

Alfaqi, M. Z, Habibi, M. M., \& Rapita, D. D. (2017). Peran Pemuda Dalam Upaya Pencegahan Korupsi dan Implikasinya Terhadap Ketahanan Wilayah (Studi Di Kota Yogyakarta, Daerah Istimewa Yogyakarta). Jurnal Ketahanan Nasional Vol.23, No.3, 320-337.

Anfajaya, M. A \& Indrawati, E. S. (2016). Hubungan Antara Konsep Diri Dengan Perilaku Asertif Pada Mahasiswa Organisatoris Fakultas Hukum Universitas Diponegoro Semarang. Jurnal Empati, Volume 5 Nomor 3, 529 - 532

Anggarasari, N. H. \& Kumolohadi, RA. R. (2012). Pelatihan komunikasi interpersonal untuk mengurangi rasa malu. Jurnal Intervensi Psikologi, Volume 4 Nomor 1, 41-55

Ali, M., \& Asrori, M., (2016). Psikologi Remaja: Perkembangan Peserta Didik. Jakarta: Bumi Aksara.

Aryani, E. (2019). Hubungan antara Konformitas Teman Sebaya dan Asertivitas dengan Perilaku Merokok pada Siswa di SMPN 2 Sleman. Prophetic: Professional, Empathy and Islamic Counseling Journal, Vo 2(1), 153-162.

Antikorupsi.org. Indonesian Corruption Watch, Tren Penindakan Kasus Korupsi 2019, https://antikorupsi.org/sites/default/files/200215tren_penindakan_kasus_korupsi_tahun_2019_final_2.pdf diakses pada tanggal 29 April 2020.

Beal, S. J. \& Crockett, L. J. (2013). Adolescents Occupational and Educational Goals: A Test of Reciprocal Relations. J Appl Dev Psychol. Vol 34 (5), 219-229.

Bhardwaj, H. \& Vishwas, M.G. (2019). Level of assertiveness among adolescent's students: A review based literature. International Journal of Advanced Scientific Research, Volume 4; Issue 2, Nomor 3, 49-5.

Branisa, B \& Ziegler, M. (2010). Reexamining the link between gender and corruption: The role of social institutions, Proceedings of the German Development Economics Conference, Berlin 2011, No. 15, http://hdl.handle.net/10419/48324

Cohen, T. R., Wolf, S. T., Panter, A. T., \& Insko, C. A. (2017). Introducing the gasp scale: A new measure of guilt and shame proneness. Journal of Personality and Social Psychology, Volume 100 Nomor 5, 947 -966.

Cunha, M., Matos, M., Faria, D, \& Zagalo, S. (2012). Shame memories and pschopathology in adolescence: The mediator effect of shame. International Journal of Psychology \& Psychological Therapy, Vol 12 (2), $203-218$. 
Desmita. (2011). Psikologi Perkembangan Peserta Didik. Bandung: PT Remaja Rosdakarya.

Dagnew, A \& Asrat, A. (2017). The Role of Parenting Style and Gender on Assertiveness among Undergraduate Students in Bahir Dar University. Saudi Journal of Humanities and Social Sciences, Volume 2 (3), 223 -229.

Hasanah, H. (2011). Dinamika psikologis perilaku korup kaum elit politik perempuan dan upaya dakwah islamiyah. Yin Yang, Vol 7(2), 12-24.

Heryadi, A., \&Yuliasari, H. (2019). Indeks Perilaku Anti Korupsi Mahasiswa. Peneltian : Fakultas Ekonomi dan SosialUnjani Yogyakarta. Laporan Penelitian. Tidak dipublikasikan,

Heryadi, A., Yuliasari, H., Ambarwati, D., \& Fathurosyiddin, H. R. (2021). Menanamkan nilai-nilai anti korupsi sejak usia dini pada anggota KOWAD KOREM 072 Pamungkas. Gervasi: Jurnal Pengabdian kepada Masyarakat, Vol. 5 (2), 230 -241.

Kementrian Pendidikan dan Kebudayaan RI. (2011). Pendidikan Anti Korupsi untuk Perguruan Tinggi. Jakarta: Kemendikbud.

Khodijah. (2018). Agama dan budaya malu sebagai kontrol sosial terhadap perilaku koruptif. Sosial Budaya, Volume 15 (2), 121-135.

Khosiin, K. (2020). Preparing Future Leader of Anti-corruption. Journal of English education and linguistics, Vol 1(2), 103-107.

Latipun. 2011. Psikologi Eksperimen. Malang: UMM Press.

Li, H., Gong, T., \& Xiao, H. (2015). The perception of anti-corruption efficacy in china: an empirical analysis. Cross Mark. Volume 125, Nomor 3, DOI:10.1007/s11205-015-0859$\underline{\mathrm{Z}}$

Luthfiany, A., Rosalina., \& Saparwati, M. (2014). Persepsi mahasiswa terhadap penerapan mata kuliah pendidikan anti-korupsi di stikes ngudi waluyo ungaran. Jurnal STIKES Ngudi Waluyo Ungaran. 1-14. https://anzdoc.com/persepsi-mahasiswa-terhadappenerapan-mata-kuliah-pendidikan.html. Diakses pada 2 April 2021

Mukodi. (2018). Anti-corruption education model for millenial generation in school. Social Science, Education and Humanities Research, Vol 287 (15-17).

Parmaksiz, I. (2019). Assertiveness as the Predictor of Adjustment to University Life amongst University Students. International Journal of Instruction, Volume.12, Nomor $4,131-148$

Parham, J. B., Lewis, C. C., Fretwell, C. E., Irwin, J. G., \& Schrimsher, M. R (2015). Influences on assertiveness: gender, national culture, and ethnicity. Journal of Management Development, 34(4), 421-439. doi:10.1108/jmd-09-2013-0113

Parray, W. M. \& Kumar, S. (2016). Assertiveness among Undergraduate Students of the University. The International Journal of Indian Psychology, 4 (8), DOI: 10.25215/0476.021.

Rotze, G. M., Ravindran, N., \& Myers, B. J. (2010). Moral emotions, emotion self-regulation, callous- unemotional traits, and problem behavior in children of incarcerated mothers. Journal of Child and Family Studies, Volume 19 Nomor 6, 702-713

Rusdi, M.I.W. \& Prasetyaningrum, S. (2015). Nilai budaya siri'na pacce dan perilaku korupsi. Jurnal Indigenous, Volume 13, Nomor 2, 68-86.

Sarkov, M., Bacikova, S., Orosova, O., Geckova, A.M., Katreniakova, Z., Klein, D., van den Heuvel, W., \& van Dijk, I.P. (2013). Associations between assertiveness, psychological well-being, and self-esteem in adolescents. Journal of applied social psychology, Volume 43 Nomor 1,47-154

Sihombing, S. O. (2018). Youth perceptions toward corruption and integrity: Indonesian context. Kasetsart Journal of Social Sciences, Volume 39 (4), 299-304.

Triyana, N. \& Heryadi, A. (2020). Kecintaan pada uang dan Persepsi Anti Korupsi. Psyche Journal, Vol. 13 (1), 44-52. 
Tangney, J.P., Stuewig, J., \& Martinez, A.G. (2014). Two faces of shame: The roles of shame and guilt in predicting recidivsm. Psychological Science, Volume 25 Nomor 3.

Uzaina \&, Parveen, A. (2015). Study of Relationship between Mental Health and Assertiveness among Adolescents. The International Journal of Indian Psychology, Volume 3, Issue 1, Nomor 5, 98-103.

Widyastuti, T. (2017). Pengaruh Komunikasi Asertif terhadap Pengelolaan Konflik. Widya Cipta, Vol 9 (1), 1-7. https://ejournal.bsi.ac.id/ejurnal/index.php/widyacipta/issue/download/171/113

Wiyoko, D. (2013). Gender and Corruption: Finding Common Ground between the AntiCorruption Movement and Women's Movement. Indonesian Feminist Journal, Vol 1, 81-93.

Yuliasari, H. \& Heryadi, A. (2020). Pelatihan anti korupsi untuk meningkatkan indeks perilaku anti korupsi pada mahasiswa FES. Jurnal Jurusan Bimbingan dan Konseling UNDIKSHA. Volume 11 (2), 127-135. 